\title{
Time to move to presumed consent for organ donation
}

\author{
Given the UK's modest 60\% consent rate \\ for donation of organs from brain stem dead \\ donors, Sheila Bird and John Harris argue \\ that allowing donation unless the donor has \\ explicitly opted out would substantially increase \\ the number of organs available
}

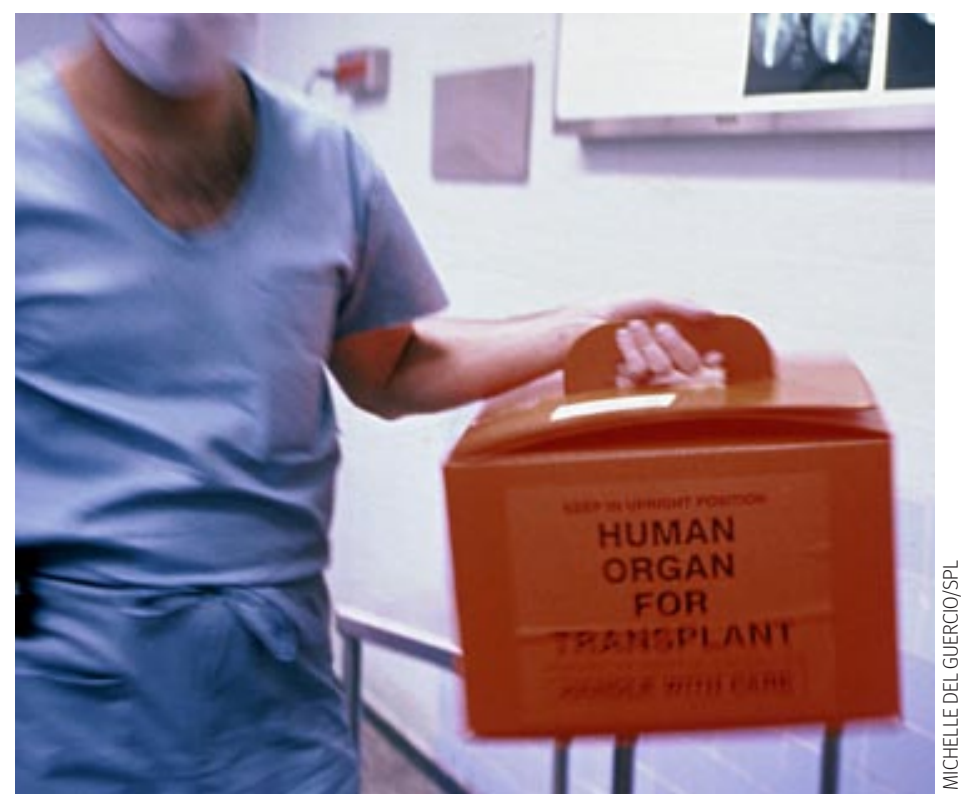

The United Kingdom's current policy on organ donation encourages people who are willing to donate organs after their death to opt-in while they are alive, rather than leave the decision to their relatives after death. In practice, even when people have expressed their willingness to donate by either carrying a donor card or, since 1994, signing up to the computerised NHS Organ Donor Register, their relatives are always asked for consent and relatives' refusal overrides the deceased would-be donor's decision.

In 2008, Prime Minister Gordon Brown asked an Organ Donor Taskforce to consider the potential effect of an opt-out system for organ donation in the UK. ${ }^{1}$ This system presumes consent unless in life the deceased person had opted out of all or organ specific donation. The taskforce commissioned research on the effect of presumed consent on organ dona-

\section{Current policy, however reinforced, will not substantially increase the number of organs available}

because the donor card might be missing when it was needed. In 1994, cards gave way to a computerised NHS Organ Donor Register, which authorised staff can consult to determine if a potential organ donor has registered his or her willingness to donate. The need for people to tell relatives about their willingness to donate persists because relatives may still overrule the deceased donor's decision.

It took nearly 15 years for 16 million people, a quarter of the UK population, to register on the Organ Donor Register. Predictably, for reasons ranging from inertia to worries about a "big brother" database state, ${ }^{5}$ the opt-in rate has been lower than the willingness to sanction organ donation recorded in public surveys. ${ }^{16}$

Relatives' willingness to allow solid organ donation from their deceased relatives has been, and still is, much higher than tion rates ${ }^{2}$ and, rather against the results of that research, ${ }^{3}$ recommended no change to current policy but renewed effort to increase the number of donors opting in. ${ }^{1}$ For example, a UK-wide network of hospital organ donation "champions" was launched in February. ${ }^{4}$

We argue that the taskforce did not consider all the relevant evidence, particularly on relatives' refusal rates, and that the current policy, however reinforced, will not substantially increase the number of organs available. By modelling different scenarios, we show that only a policy of presumed consent will substantially increase the number of organs available for transplantation.

\section{UK donation}

In the late 1980s, the UK's publicity for organ donation urged people to "Carry the Card" to indicate their willingness to donate and to tell their relatives the current opt-in rate to the Organ Donor Register. In the late 1980 s, around $70 \%$ of relatives gave consent for organ donation, ${ }^{7-9}$ and, although the rate has since fallen, it is still around 60\%. ${ }^{10}$

\section{Holding back the hands of success}

The specialty of transplant surgery has succeeded in adding life years cost effectively by using immunology and statistical science to deliver optimal, equitable matching of donor organs to recipients. ${ }^{11-18}$

In 1989-90, a confidential audit of all deaths in intensive care units in England and Wales clearly showed that relatives' refusal was the main reason for recipients missing out on cadaveric kidney transplantation..$^{7-9}$ Although $94 \%$ of the families of 1939 brain stem dead potential donors were asked about organ donation, $30 \%$ of the 1829 refused consent ( $95 \%$ confidence interval $28 \%$ to
$33 \%)$. When the family did give consent, organs were not retrieved in only $3 \%$ of cases (table 1). High intensity, sustained positive publicity about transplantation reduces relatives' refusal rate, but only by a quarter. ${ }^{9}$

More recently, the UK potential donor audit has shown that relatives' refusal has risen to $40 \%{ }^{10}$ and that the refusal rate by families of non-white patients is even higher: $74 \% v 32 \%(\mathrm{P}<0.0001)$ in the two years to 31 March $2008 .{ }^{19}$ In the two years to 31 March 2007, 9\% of families refused "authorisation" despite the deceased's registration on the Organ Donor Register (27/294; 95\% confidence interval $6 \%$ to $13 \%$ ).

For whatever reasons, altruistic donation has fallen in the past decade and differs between ethnic groups. This is despite better outcomes from transplantation and the support of all the UK's major religions for the principles of organ donation and transplantation.

\section{Taskforce conclusions}

The Organ Donor Taskforce commissioned a team to assess the impact of presumed consent on organ donation rates. ${ }^{2}$ Its report was essentially a systematic review of three sorts of published study: before and after studies, international comparisons, and surveys of attitudes to presumed consent. ${ }^{3}$ The five before and after "presumed consent" comparisons in three countries all documented substantial increases of at least five deceased organ donors per million population. The four out of the eight international comparisons that the report's authors judged to be of good quality (for example, because of adjustment for cofactors) found that increases of around $25 \%$, or three to six deceased donors per million population, were associated with presumed consent.

The assessment team concluded: "Presumed consent is associated with increased organ dona- 
tion rates, even when other factors are accounted for. However, it cannot be inferred from this that the introduction of presumed consent legislation per se will lead to an increase in organ donation rates."2 The team thus properly acknowledged that, even after adjusting for cofactors, association is not the same as causation. However, the taskforce misreported the team's findings by referring to "apparent correlation" between presumed consent and donation rates. The correlation was real, not apparent, but causality could not be inferred directly. Parry, a member of the taskforce, even gave a seemingly reversed account: "Presumed consent would not increase the numbers of donors and might do the opposite." 20

The taskforce prevaricated over a switch to presumed consent and an associated opt-out register, partly on grounds of $\operatorname{cost}^{21}$ but also because of a concern about families' need to "authorise" donation. Yet in the UK there are fewer than 3000 confirmed brain stem deaths a year in which presumed consent for organ donation, as a public good, would apply (table 1) if the deceased had not opted out in life. For comparison, over 120000 coronial or fiscal postmortem examinations are done in the UK each year. They too are a public good but do not require "authorisation" from the family. Overall, the taskforce's opposition was contrary both to its own evidence $e^{2320}$ and to evidence that it did not consider-which also favours presumed consent.

\section{Other evidence}

In 2007, the European Union's Directorate General for Health and Consumers reported rates of deceased and living organ donation in EU countries. ${ }^{6}$ Table $2^{2}$ shows data from four countries with presumed consent (Spain, Belgium, France, and Austria) and from the Netherlands and UK, which both recently rejected it. The countries with presumed consent had the higher rates of deceased organ donation per million population and the lower rates of living kidney transplantations. The report also included a survey of willingness to give consent for donation of a close family member's organs (typically based on 1000 face to face interviews in each country and hence a standard error of about $1.5 \%$ ). The rate of consent was similar for all six countries in table 2 . The highest consent rates were recorded elsewhere-in Finland (73\%) and Sweden (74\%).

\section{Evidence from UK audits}

Perhaps the Organ Donor Taskforce's most serious shortcoming, however, was its failure to exploit the UK's potential donor audit ${ }^{10}$ to measure, under different scenarios, the additional number of kidney, pancreatic, liver, heart, and thoracic transplantations that there could have been in the past 10 years from donations after brain stem death.

We have used data from the three audits over the past 20 years (table 1 ) to consider the effect of four
Table 1 | Comparison of confidential audits of intensive care units. Values are numbers (percentages) unless stated otherwise

\begin{tabular}{|c|c|c|c|}
\hline & \multicolumn{3}{|c|}{ Audit } \\
\hline & $1989-90 * 9$ & $2003-5 t^{10}$ & $2006-8 \ddagger^{19}$ \\
\hline Total No of deaths & 24023 & 46801 & 30276 \\
\hline $\begin{array}{l}\text { Brain stem death was a } \\
\text { possible diagnosis }\end{array}$ & $3266(13.6)$ & $4166(8.9)$ & $3184(10.5)$ \\
\hline Brain stem death tests done & $2466(10.3)$ & $2857(6.1)$ & $2475(8.2)$ \\
\hline $\begin{array}{l}\text { Criteria met before cessation } \\
\text { of heart beat }\end{array}$ & $2389(9.9)$ & $2754(5.9)$ & $2417(8.0)$ \\
\hline $\begin{array}{l}\text { No general medical } \\
\text { contraindication to organ } \\
\text { donation§ }\end{array}$ & $1951(8.1)$ & $2740(5.9)$ & $2407(8.0)$ \\
\hline $\begin{array}{l}\text { Patients with no known } \\
\text { relatives }\end{array}$ & 12 & Not available & Not available \\
\hline $\begin{array}{l}\text { Donation not discussed or not } \\
\text { considered }\end{array}$ & 110 & 273 & 141 \\
\hline $\begin{array}{l}\text { Donation considered, not } \\
\text { discussed }\end{array}$ & & 147 & 141 \\
\hline $\begin{array}{l}\text { Donation refused (as \% of } \\
\text { families asked) }\end{array}$ & $557(30)$ & $941(41)$ & $826(39)$ \\
\hline Offered, not retrieved & 40 & 135 & 113 \\
\hline $\begin{array}{l}\text { Consent, deceased became } \\
\text { organ donor (as \% of } \\
\text { confirmed brain stem deaths) }\end{array}$ & $1232(52) 1192(50) 9$ & $1244(45)$ & $1186(49)$ \\
\hline \multicolumn{4}{|l|}{$\begin{array}{l}\text { Refusal rate by ethnicity of } \\
\text { deceased }(\%)^{\star *} \text { : }\end{array}$} \\
\hline White & Not asked & $33-37$ & 32 \\
\hline Non-white & Not asked & $63-77$ & 74 \\
\hline
\end{tabular}

*Audit of all deaths in intensive care units in England (1989-90) and Wales (1990).

tAudit of UK intensive care records 1 April 2003 to 31 March 2006.

$\ddagger$ Audit of UK intensive care records 1 April 2006 to 31 March 2008.

$\S$ Contraindications differed between audits before and after 2000.

I) Number (\%) of solid organ donors.

$\star \star 95 \%$ confidence interval or estimated refusal rate.

\begin{tabular}{|c|c|c|c|c|}
\hline Country & Policy & $\begin{array}{c}\text { Deceased organ } \\
\text { donor rate/ million } \\
\text { population }\end{array}$ & $\begin{array}{l}\text { Living kidney } \\
\text { transplants/million } \\
\text { population }\end{array}$ & $\begin{array}{c}\text { Relatives' consent } \\
\text { rate* }(\%)\end{array}$ \\
\hline Spain & $\begin{array}{l}\text { Presumed consent with } \\
\text { family override }\end{array}$ & 34 & 2 & 59 \\
\hline Belgium & $\begin{array}{l}\text { Presumed consent with } \\
\text { family override }\end{array}$ & 27 & 4 & 65 \\
\hline France & $\begin{array}{l}\text { Presumed consent with } \\
\text { family override }\end{array}$ & 23 & 4 & 61 \\
\hline Austria & $\begin{array}{l}\text { Presumed consent. } \\
\text { Family cannot override }\end{array}$ & 19 & 7 & NA \\
\hline UK & Rejected opt-out & 13 & 11 & 63 \\
\hline Netherlands & Rejected opt-out & 13 & 17 & 66 \\
\hline
\end{tabular}

*Around 1000 people in each country were asked in face to face interviews: "If you were asked in a hospital to donate an organ from a deceased close family member, would you agree?"

Table 3 |Effect of four scenarios for organ donation on availability of organs over 10 years extrapolating from data from UK audits for 2003-5 and 2006-8 (table 1)

\begin{tabular}{|c|c|c|c|c|c|}
\hline Scenario & Description & Opt-out rate & $\begin{array}{l}\% \text { refusal by } \\
\text { relatives }\end{array}$ & $\begin{array}{c}\text { No of solid organ } \\
\text { donors }\end{array}$ & $\begin{array}{c}\text { Extra donors over } \\
\text { baseline }\end{array}$ \\
\hline Current & Opt-in: 21st century & NA & 40 & $6050^{*}$ & Baseline \\
\hline 1 & $\begin{array}{l}\text { Opt-in as in 1989- } \\
90\end{array}$ & NA & 30 & $7060 \dagger$ & 1010 \\
\hline 2 & $\begin{array}{l}\text { Presumed consent: } \\
\text { plausible }\end{array}$ & 10 & 10 & $8930 \ddagger$ & 2880 \\
\hline 3 & $\begin{array}{l}\text { Presumed consent: } \\
\text { pessimistic }\end{array}$ & 5 & 40 & $6280 \S$ & 230 \\
\hline 4 & $\begin{array}{l}\text { Mandatory } \\
\text { donation }\end{array}$ & NA & NA & 102809 & 4230 \\
\hline
\end{tabular}

*(5147-288-414)×0.6(consent rate) $\times 0.907$ (retrieval rate) $\times 10 / 4$ (pro rata for 10 years).

$\mathrm{t}(5147-288-414) \times 0.7 \times 0.907 \times 10 / 4$.

$\ddagger(5147-288) \times 0.9($ rate not opting out $) \times 0.9$ (relatives' consent rate $) \times 0.907 \times 10 / 4$.

$\S(5147-288) \times 0.95 \times 0.6 \times 0.907 \times 10 / 4$.

ПBased on 2006-8 data only: $(2407-141) \times 0.907 \times 10 / 2$ (pro rata for 10 years). 
scenarios against a 21st century baseline of opt-in with relatives' refusal rate of $40 \%$ : (1) opt-in with relatives' refusal rate reduced to $30 \%$ as in 1989 90; (2) plausible presumed consent scenario with $10 \%$ opt-out rate and $10 \%$ override by families; (3) pessimistic presumed consent with $5 \%$ opt-out rate but $40 \%$ override by families; and (4) mandatory solid organ donation, as first advocated in $1983 .{ }^{22}$

We extrapolated each scenario over 10 years (table 3). Scenarios 1 to 3 are based on 5147 confirmed brain stem deaths over four years in patients with no general medical contraindications (from the 2003-5 and 2006-8 audits in table 1). We deducted the 288 cases where solid organ donation was "considered but not discussed," which we interpret as some other form of medical contraindication to donation. Scenario 4 assumes mandatory solid organ donation after brain stem death in an intensive care unit if the deceased was under 75 years old and is based on only the 2006-8 audit data. For each scenario, we used a $90.7 \%$ (2430/2678) retrieval rate from offered donors, which is the combined rate for the 2003-5 and 2006- 8 audits. Table 3 summarises the results to the nearest 10 donations.

Scenario 1-The current opt-in policy applies but families' refusal rate reduces from $40 \%$ to $30 \%$, as it was in 1989-90..$^{7-9}$ In scenario 1 we should have had 7060 solid organ donors (to nearest 10) over 10 years versus a baseline of 6050 with $40 \%$ relatives' refusal rate ${ }^{10}$ and so an estimated 1010 extra solid organ donors.

Scenario 2-Presumed consent with a conservatively high $10 \%$ of people explicitly opting out of donation, and we also assume that $10 \%$ of donations are overridden by families. Notice that a 10\% opt-out rate exceeds refusals (by 4/111 UK families) of authorisation for research use of tissue from forensic postmortems ${ }^{23}$ and far exceeds Belgium's opt-out rate from donation. ${ }^{24}$ Table 3 shows that we should have had 8930 solid organ donors over 10 years, and so an estimated 2880 extra solid organ donors.

Scenario 3-Presumed consent with 5\% opt-out rate but, pessimistically, we assume that $40 \%$ of "presumed consents" are over-ridden by relatives' refusal. This would have given 6280 solid organ donors over 10 years, only an estimated 230 extra solid organ donors.

Scenario 4-assumes a policy of mandatory solid organ donation after brain stem death in intensive care units in all patients aged under 75 years. In this maximal scenario we should have had 10280 solid organ donors over 10 years and so an estimated 4230 extra solid organ donors.

\section{Conclusions}

Reducing relatives' refusal rate by a quarter is difficult even with sustained positive publicity for transplantation, as the 1989-90 confidential audit showed. Twenty years of effort at transplant coordination in the UK warn that the Organ Donor Taskforce is unrealistic if it reckons to do better than scenario 1 without adopting a policy of presumed consent.

Changing the presumption, however, has the potential to deliver $68 \%$ (2880/4230) of the extra solid organ donors that mandatory donation would give. But scenario 3 warns that if changed presumption is not associated with a reduction in relatives' refusal, the gain could be slight or even negative.

Transplants save lives, ${ }^{25}$ and so a shift of perspective is overdue. This would be helped if, besides reporting on the number and outcome of actual transplantations, UK's Organ Donation and Transplantation Directorate also reported the number of transplantable solid organs that were lost to transplantation because of $(a)$ relatives' refusal, (b) non-retrieval of offered suitable organs, $(c)$ and other reasons.

Twenty years after the UK's first confidential audit, we continue to jeopardise substantial quality adjusted life years (uncounted by the Organ Donor Taskforce) for those awaiting transplantation by chasing a holy grail of enhanced consent by means other than presumption. Presumed consent, even allowing for over-rule by relatives, should ultimately cut costs (because an opt-out register would have at most 6 million registrations, and probably nearer to 3 million), add life, and save bereaved families from anxious, as well as generous, deliberation in extremis.

Sheila M Bird senior scientist, MRC Biostatistics Unit, Cambridge CB2 OSR

John Harris director, Institute for Science, Ethics and Innovation, Manchester M139PL

Correspondence to:S M Bird sheila.bird@mrc-bsu.cam.ac.uk

Contributors and sources: $\mathrm{HH}$ is joint editor in chief of the Journal of Medical Ethics and was a member of the BMA ethics committee. SMB has worked on transplantation statistics for over a decade. Both authors contributed to the writing and editing of the article, for which SMB is the guarantor.

Competing interests: SMB is funded by the Medical Research Council (WBS No U.1052.00.002.00001.01). JH has had support from the Wellcome Trust strategic programme "The Human Body, Its Scope, Limits and Future."

Provenance and peer review: Not commissioned; externally peer reviewed.

1 Organ Donor Taskforce. The potential impact of an opt out system for organ donation in the UK. DH, 2008. www. dh.gov.uk (search for product No 291525).

2 Rithalia A, McDaid C, Suekarran S, Myers L, Sowden A. Impact of presumed consent for organ donation on donation rates: a systematic review. $B M$ 2009;338:a3162.
3 English V, Sheather J, Sommerville A, Chrispin E. Ethics briefings: taskforce rejects presumed consent for organ donation. J Med Ethics 2009;35: 335-6.

4 NHS Blood and Transplant. Professional development programme to improve organ donation. Press release, 27 Jan 2010. www.organdonation.nhs.uk/ukt/newsroom/ news_releases/article.jsp?releaseld=243.

5 Anderson R, Brown I, Dowty T, Inglesant P, Heath W, Sasse A. Database state. A report commissioned by the Joseph Rowntree Trust Foundation. 2009. www.cl.cam. ac.uk/ rja14/Papers/database-state.pdf.

6 EU Directorate for Health and Consumers. Key facts on EU organ donation and transplantion. www.cosac.eu/en/ info/earlywarning/organ donation.pdf/facts.pdf.

7 Gore SM, Hinds C), Rutherford AJ. Organ donation from intensive care units in England. BMJ 1989;299:1193-7.

8 Gore SM, Ross RMR, Wallwork J. Availability of transplantable organs from brain stem dead donors in intensive care units. BMJ 1991;302:149-53.

9 Gore SM, Cable DJ, Holland AJ. Organ donation from intensive care units in England and Wales: two year confidential audit of deaths in intensive care. $B M$ J 1992;304:349-55.

10 Barber K, Falvey S, Hamilton C, Collett D, Rudge C. Potential for organ donation in the United Kingdom: audit of intensive care records. BMJ 2006;332:1124-7.

11 Fuggle SV, Johnson RJ, Rudge CJ, Forsythe JLR. Human leukocyte antigen and the allocation of kidneys from cadaver donors in the United Kingdom. Transplantation 2004;77:618-20.

12 Taylor DO, Edwards LB, Boucek MM, Trulock EP, Aurora $\mathrm{P}$, Christie J, et al. Registry of the International Society for Heart and Lung Transplantation: twenty-fourth official adult heart transplant report-2007. J Heart Lung Transplant 2007;26:769-81.

13 Sharples LD, Jackson CH, Parameshwar J, Wallwork J, Large SR. Diagnostic accuracy of coronary angiography and risk factors for post-heart-transplant cardiac allograft vasculopathy. Transplantation 2003;76:679-82.

14 Burroughs AK, Sabin CA, Rolles K, Delvart V, Karam V, Buckels J, et al. 3-month and 12-month mortality after first liver transplant in adults in Europe: predictive models for outcome. Lancet 2006;367:225-32.

15 Bird SM, Calne RY, Sharples LD. Analyse transplant outcomes in distinct epochs of follow-up. Lancet 2006;367:1816.

16 Oto T, Levvey BJ, Whitford H, Griffiths AP, Kotsimbos T, Williams TJ, et al. Feasibility and utility of a lung donor score: correlation with early post-transplant outcomes. Ann Thoracic Surg 2007;83:257-63.

17 Darke J. Invited commentary. Ann Thoracic Surg 2007;83:264.

18 Persad G, Wertheimer A, Emanuel EJ. Principles for allocation of scarce medical interventions. Lancet 2009;373:423-31.

19 Potential donor audit. UK Transplant Bulletin 2008 Winter (issue 68): 11.

20 Organ Donation Taskforce. Annex G: an opt out system initial cost analysis. Supporting information for the potential impact of an opt out system for organ donation in the UK. www.dh.gov.uk/prod_consum_dh/groups/ dh_digitalassets/@dh/@en/documents/digitalasset/ dh_090310.pdf.

21 Parry V. Why we said no to presumed consent. Times 2008 Nov 18. www.timesonline.co.uk/tol/comment/ columnists/guest_contributors/article5175519.ece.

22 Harris J. In vitro fertilisation: the ethical issues. Philosoph Q 1983;33:217-38.

23 Millar T, Walker R, Arango J-C, Ironside JW, Harrison DJ, Maclntyre DJ, et al. Tissue and organ donation for research in forensic pathology: the MRC sudden death brain and tissue bank. J Pathol 2007;213:369-75.

24 Michielsen P. Presumed consent to organ donation: 10 years' experience in Belgium. J R Soc Med 1999;89: 663-6.

25 NHS UK Transplant. Statistics. Transplants save lives. October 2009. www.uktransplant.org.uk/ukt/statistics/ statistics.jsp.

Cite this as: BM/ 2010;340:c2188 